\title{
ACTIVE or not, high intensity is here to stay
}

\author{
Judson B. Williams, MD, MHS
}

\footnotetext{
From the Department of Cardiovascular and Thoracic Surgery, WakeMed Health and Hospitals, Duke University School of Medicine, Raleigh, NC

Disclosures: Author has nothing to disclose with regard to commercial support.

Received for publication June 16, 2018; revisions received June 16, 2018; accepted for publication June 18, 2018; available ahead of print Aug 8, 2018.

Address for reprints: Judson B. Williams, MD, MHS, Cardiovascular and Thoracic Surgery, WakeMed Health and Hospitals, Duke University School of Medicine, 3000 New Bern Ave, Suite 1100, Raleigh, NC 27610 (E-mail: judson.williams@duke.edu).

J Thorac Cardiovasc Surg 2019;157:147-8

$0022-5223 / \$ 36.00$

Copyright (c) 2018 by The American Association for Thoracic Surgery

https://doi.org/10.1016/j.jtcvs.2018.06.056
}

The Aggressive Cholesterol Therapy to Inhibit Vein Graft Events (ACTIVE) trial, the first randomized, controlled trial to evaluate the impact of early postoperative high-intensity lipid-lowering therapy on vein graft patency after coronary artery bypass grafting (CABG) surgery, is presented in this issue of the Journal by Kulik and colleagues. ${ }^{1}$ The study was designed by a group of international experts on aortocoronary bypass graft patency and lipid management.

The conduct of ACTIVE began in 2012, and guidelines at the time for lipid-lowering therapy after CABG surgery were for a target low-density lipoprotein level lower than $100 \mathrm{mg} / \mathrm{dL}$. In the interim, however, American Heart Association guidelines have changed in response to several high-quality primary and secondary prevention studies that reported benefits with high-intensity statin therapy. In fact, Drs Kulik and Ruel, ACTIVE's principal investigators, are among the group of experts giving a class I, level of evidence A recommendation for atorvastatin at 40 to $80 \mathrm{mg}$ or rosuvastatin at 20 to $40 \mathrm{mg}$ for all patients after CABG, with the exception of those patients intolerant of high-intensity therapy or those at greater risk for drug-drug interactions. ${ }^{2}$

With the publication of these new guidelines, enrollment in ACTIVE was terminated with 173 patients enrolled. Through 1-year follow-up, all vein graft end points favored the atorvastatin 80-mg high-dose statin group, although statistical significance was, as would be expected, not achieved $(29.2 \%$ vs $19.2 \%$ with development of vein graft disease; $P=.18$ )

Not discussed in the written presentation of Kulik and colleagues $^{1}$ is the pathophysiology of vein graft disease. Endothelial damage during exposure of saphenous veins to systemic arterial pressure leads to platelet adherence to the intima. Smooth muscle cell migration is then stimulated, resulting in intimal hyperplasia; with time, lipid may become incorporated in areas of hyperplasia, resulting in atherosclerotic plaques and ultimately vein graft stenosis and occlusion. In addition to lowering lipids, statins also attenuate the proliferation of vascular smooth muscle

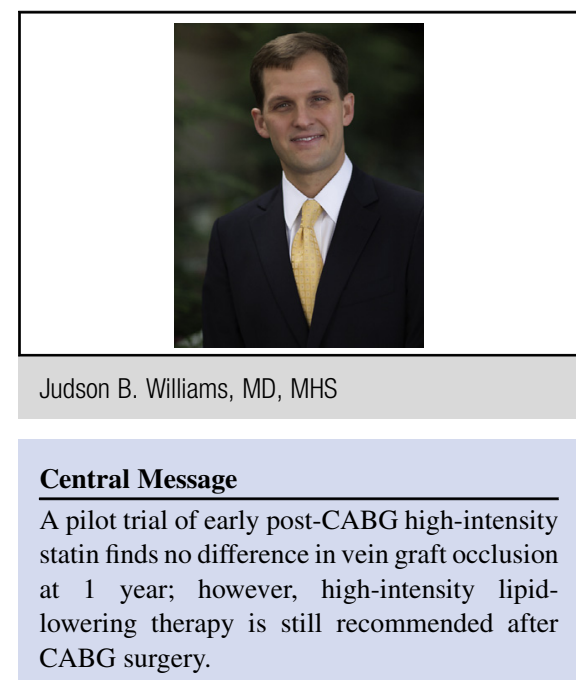

See Article page 151

cells and increase endogenous nitric oxide, potential mechanisms for early post-CABG benefit. The period of atherosclerotic change with lipid deposition is believed to occur a year out from the time of the operation, which is the time at which gated coronary angiography was performed in ACTIVE. Understanding this, many readers will reach the conclusion that later follow-up of even the present cohort, not to mention a larger cohort, would probably have resulted in a demonstrable benefit to high-intensity lipidlowering therapy.

With the change in guidelines and the cost needed to randomly allocate 1300 patients for a randomized, controlled trial powered on the ACTIVE results, ACTIVE is not likely to leave the pilot phase. Other intriguing arenas exist for future randomized study, including proprotein convertase subtilisin/kexin type 9 inhibition, which can achieve low-density lipoprotein levels lower than $10 \mathrm{mg} / \mathrm{dL}$. Concerns regarding statin liver injury will be validated by the finding that $3.5 \%$ of ACTIVE's high-intensity group had elevated liver enzymes, as opposed to $0 \%$ in the lower dose group. Adoption of the latest American Heart Association secondary prevention guidelines for high-intensity lipid-lowering therapy will not be immediate and will require leadership from surgeons if this therapy is to become part of routine clinical care for our patients. ${ }^{3}$ I congratulate Kulik and colleagues ${ }^{1}$ on their work and look forward to longer-term results from these 173 randomly assigned patients in the years to come. With ACTIVE or not, however, high-intensity lipid-lowering therapy appears here to stay. 


\section{References}

1. Kulik A, Abreu AM, Boronat V, Ruel M. Intensive versus moderate statin therapy and early graft occlusion after coronary bypass surgery: the Aggressive Cholesterol Therapy to Inhibit Vein Graft Events randomized clinical trial. J Thorac Cardiovasc Surg. 2019;157:151-61.

2. Kulik A, Ruel M, Jneid H, Ferguson TB, Hiratzka LF, Ikonomidis JS, et al; American Heart Association Council on Cardiovascular Surgery and Anesthesia. Secondary prevention after coronary artery bypass graft surgery: a scientific statement from the American Heart Association. Circulation. 2015;131:927-64.

3. Williams JB, De Long ER, Peterson ED, Dokholyan RS, Ou FS, Ferguson TB; Society of Thoracic Surgeons and the National Cardiac Database. Secondary prevention after coronary artery bypass graft surgery: findings of a national randomized controlled trial and sustained society-led incorporation into practice. Circulation. 2011;123:39-45.

Access to The Journal of Thoracic and Cardiovascular Surgery Online is reserved for print subscribers!

Full-text access to The Journal of Thoracic and Cardiovascular Surgery Online is available for all print subscribers. To activate your individual online subscription, please visit The Journal of Thoracic and Cardiovascular Surgery Online, point your browser to http://www.mosby.com/jtcvs, follow the prompts to activate your online access, and follow the instructions. To activate your account, you will need your subscriber account number, which you can find on your mailing label (note: the number of digits in your subscriber account number varies from 6 to 10). See the example below in which the subscriber account number has been circled:

\section{Sample mailing label}

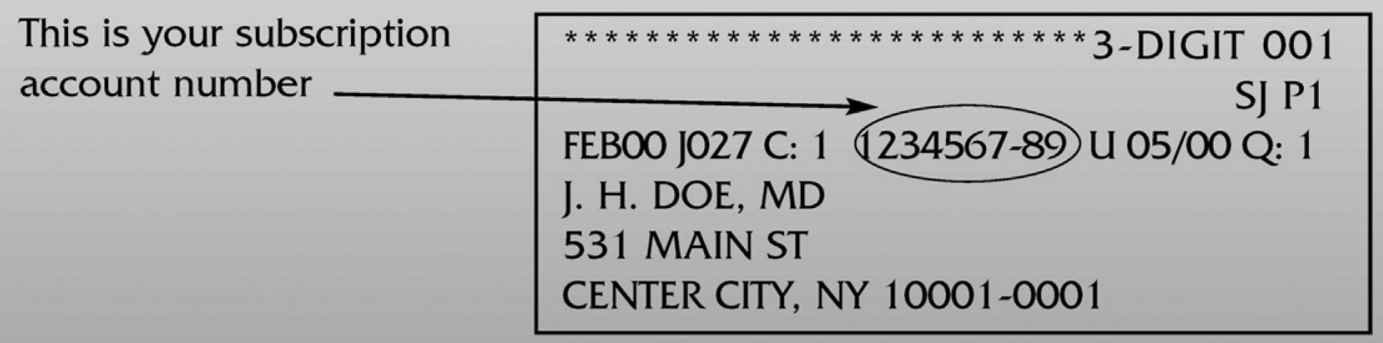

Personal subscriptions to The Journal of Thoracic and Cardiovascular Surgery Online are for individual use only and may not be transferred. Use of The Journal of Thoracic and Cardiovascular Surgery Online is subject to agreement to the terms and conditions as indicated online. 